\title{
PENGESANAN KENYAHWUJUDAN NAJIS BERDASARKAN KAEDAH ANALISIS PROFIL DNA FORENSIK: SATU ANALISIS HUKUM ${ }^{1}$
}

\section{Detection of Excrement Degradation Based on Forensic DNA Profiling Method: An Analysis from Fiqh View}

\author{
Mohd Hapiz Mahaiyadin ${ }^{2}$ \\ Roshaimizam Suhaimi ${ }^{3}$ \\ Ainorkhilah Mahmood ${ }^{4}$ \\ Nor Fariza Ismail ${ }^{5}$ \\ Hisyam Mohd Radzi ${ }^{6}$
}

$1 \quad$ Setinggi penghargaan kepada Jabatan Mufti Negeri Pulau Pinang (100-IRMI/GOV 16/6/2 (0003/2019) yang telah menaja projek kajian ini. Kajian telah dijalankan di Makmal Kejuruteraan Kimia, Universiti Teknologi Mara, Cawangan Pulau Pinang dan analisa kimia telah dijalankan di Unit Forensik, Jabatan Kimia Negeri Pulau Pinang.

2 Senior Lecturer, Academy of Contemporary Islamic Studies, Universiti Teknologi MARA, 40450 Shah Alam, Selangor, mohdhapiz659@uitm.edu.my

3 Senior Lecturer, Academy of Contemporary Islamic Studies, Universiti Teknologi MARA, Cawangan Pulau Pinang, 13500 Permatang Pauh, Pulau Pinang, roshaimizam@uitm.edu.my

4 Senior Lecturer, Department of Applied Sciences, Universiti Teknologi MARA, Cawangan Pulau Pinang, 13500 Permatang Pauh, Pulau Pinang, ainorkhilah_sp@ uitm.edu.my

5 Senior Lecturer, Faculty of Chemical Engineering, Universiti Teknologi MARA, Cawangan Pulau Pinang, 13500 Permatang Pauh, Pulau Pinang, norfariza5031@, uitm.edu.my

6 Senior Lecturer, Academy of Contemporary Islamic Studies, Universiti Teknologi MARA, Cawangan Pulau Pinang, 13500 Permatang Pauh, Pulau Pinang, hisyammr@uitm.edu.my 


\begin{abstract}
Nowadays, some people have doubts about the ability of washing machine and laundry machine to remove impurities (najis) because the use of these machines has never been discussed by fuqaha' in the past. Therefore, this study is aimed at identifying the existence of impurities after washing according to the method of purification of Shäfi'is madhhab. Three samples of blood, urine and baby stool were used on the clothes. All samples were tested using two methods - the Kestle-Meyer Test (KM-Test) and Forensic DNA Profile Analysis at the Penang State Department of Chemistry Forensic Lab. The results of the KM-Test test on blood samples have shown negative results. While urine samples and baby stools cannot be detected directly. In addition, the DNA profile analysis also showed similar results that before washing, the presence of najis in blood control samples was detected only at $44.80 \mathrm{ng} / \mu \mathrm{l}$ (sample A) and 65. $00 \mathrm{ng} / \mu \mathrm{l}$ (sample B) and after washing, the effect on samples $A$ and $B$ in the laundry wash were only $1.78 \mathrm{ng} / \mu \mathrm{l}$ and $3.28 \mathrm{ng} / \mu \mathrm{l}$. While in the washing machine, there were only $3.28 \mathrm{ng} / \mu \mathrm{l}$ in sample A and $1.11 \mathrm{ng} /$ $\mu l$ in sample B. Furthermore, this study concluded that washing machine and laundry machine successfully remove the impurities from clothing.
\end{abstract}

Keywords: tahārah, impurities, clothing, water and washing

\title{
PENDAHULUAN
}

Asas kebersihan diri ataupun tahārah merupakan tuntutan syarak ke atas setiap individu Muslim. Tuntutan tersebut berdasarkan nas al-Quran dan sunah Rasulullah SAW. Dalam al-Quran, Allah SWT menyatakan tentang kepentingan menjaga kebersihan rohani dan jasmani serta menyintai sekalian hambaNya yang sentiasa membersihkan jiwa mereka daripada pelbagai kotoran termasuk maksiat dan dosa:

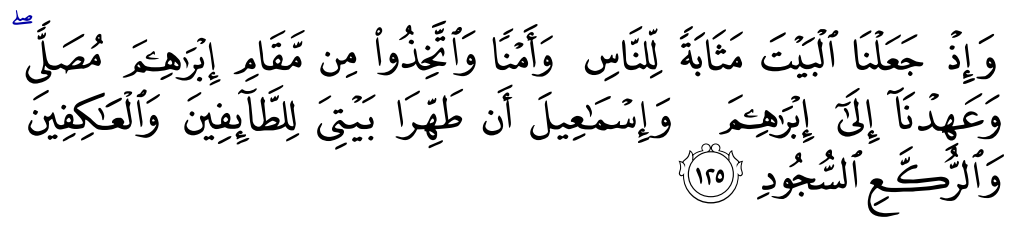

"Dan (ingatlah), ketika Kami menjadikan rumah itu (Baitullah) tempat berkumpul bagi manusia dan tempat yang aman. dan 
Jadikanlah sebahagian maqam Ibrahim akan tempat solat dan telah Kami perintahkan kepada Ibrahim dan Ismail: Bersihkanlah rumah-Ku untuk orang-orang yang tawaf, yang iktikaf, yang rukuk dan yang sujud."

(Surah al-Baqarah, 2: 125)

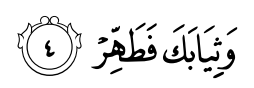

"Dan pakaianmu bersihkanlah"

(Surah al-Muddaththir, 74: 4)

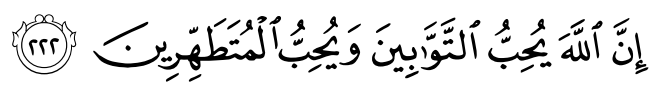

"Sesungguhnya Allah menyukai orang-orang yang bertaubat dan menyukai orang-orang yang mensucikan diri. "

(Surah al-Baqarah, 2: 222)

Perkara sama turut dinyatakan dalam sunnah Rasulullah SAW seperti yang berikut:

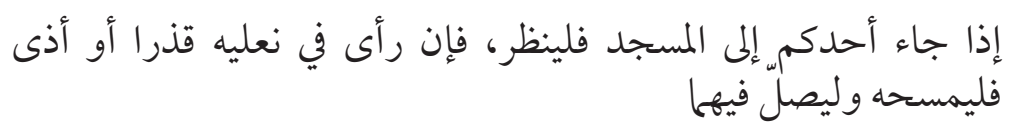

“Apabila seseorang daripada kalian pergi ke masjid, hendaklah dia perhatikan. Maka jika terlihat terdapat kotoran di kedua-dua sandalnya, hendaklah disapu (dibersihkan) dan bersolat dengan memakainya (selepas dibersihkan)." 7

Nas-nas di atas menunjukkan bahawa pelbagai kotoran dan najis wajib dibersihkan kerana semua itu merupakan najis yang menghalang kesahihan ibadat solat.

Pada masa kini, mesin basuh dan dobi merupakan satu kemudahan untuk membasuh pakaian kotor termasuk yang terkena najis. Walaupun kedua-dua mesin tersebut menggunakan air, namun teknik basuhan dengan penggunaan kuantiti air yang sedikit menyebabkan berlaku pertikaian dalam kalangan sarjana hukum masa kini mengenai status kebersihan pakaian bernajis. Pertikaian tersebut disebabkan pemahaman masing-masing terhadap amalan

\footnotetext{
Abī Dāwud, Sulayman Ibn al-Ash'ath al-Sijistānī al-'Azdī, Sunan Abī Dāwūd, ed. Muhammad Muhy al-Dīn 'Abd al-Ḥamīd (Bayrūt: al-Maktabah al-'Asriyyah, t.t.), 175, Bāb al-Șalāh fi al-Na’l, no. hadis 650 .
} 
țahārah dalam kitab-kitab fiqh mazhab. Terdapat sebahagian ulama yang menghukumkan pakaian tersebut bersih dan sebahagian lain menyatakan sebaliknya. Ini berpandukan hujah yang merujuk kepada status percampuran air bersih kurang dua kolah $^{8}$ dengan pakaian bernajis dan keupayaan keduadua mesin tersebut menghilangkan kesan najis seperti bau, warna dan rasa.

Beberapa pengkaji semasa telah menyentuh isu di atas daripada pelbagai perspektif. Kebanyakannya berpandukan kepada perbahasan fuqaha silam mengenai kaedah pembersihan dengan air dan syarat-syarat aplikasinya. Hukum pembersihan najis dibincangkan oleh 'Abd al-Hāsib 'Ațiyyah secara perbandingan antara empat mazhab, tetapi tidak menyentuh tentang penggunaan mesin basuh. ${ }^{9}$ Jamāl Șālih dalam disertasi sarjananya bertajuk 'Wasā'il al-Tațīr', hanya membincangkan kaedah pembersihan melalui kaedah istihālah secara lebih luas. ${ }^{10}$ Setiap kaedah dianalisa berdasarkan teori yang dikemukakan oleh fuqaha' klasik dan diaplikasikan dalam beberapa permasalahan termasuklah permasalahan moden, namun tidak disentuh secara terperinci isu kaedah penyucian menggunakan mesin basuh moden.

Kaedah pembersihan najis turut dijelaskan oleh Wahbah al-Zuhaylī dalam huraiannya tentang tahärah. Beliau membahaskan secara terperinci berkaitan kaedah penyucian air atau pakaian yang terkena najis dengan melihat kepada pelbagai pandangan fuqaha silam dalam masalah ini. Namun, tidak disentuh pula secara jelas kaedah basuhan mesin basuh dan dobi. ${ }^{11}$

8 Menurut Șāliḥ Ḥasan al-Rayyāshī, kadar sukatan air dua kolah pada hari ini bersamaan 216 liter. Manakala menurut 'Alī Jum'ah pula, ukurannya mengikut kadar timbangan/berat adalah seperti yang berikut; 1 kolah bersamaan 250 kati Baghdad [Iraqi]. 1 kati Baghdad bersamaan 382.5 gram. 1 kolah (250 kati) x 382.5 gram $=92,625$ gram $/ 92.625 \mathrm{~kg}$. Maka jumlah 2 kolah $(92.625 \mathrm{~kg}) \times 2=(+/-)$ $191.25 \mathrm{~kg}$. Manakala dari segi sukatan liter, ia bersamaan $191.25 \mathrm{~kg}$ x $1.04 \mathrm{Liter}(1$ $\mathrm{kg}=(+/-) 1.04$ liter $)=(+/-)$ 198.9 Liter. Lihat al-Rayyashī, Șāliḥ Hasan, al-Sharh al-Manhajī al-Mu 'āṣir li Alfāz al-Faqīh Abì Shujā' al-Shāfi 'ī, 58; 'Alī Jum'ah, alMakāyil wa al-Mawāzin al-Shar 'iyyah (Qāhirah: al-Quds li al-Nashr wa al-I'lān, 2001), 42. Rujuk juga https://muftiwp.gov.my/en/artikel/al-kafi-li-al-fatawi/3413al-kafi-1263-hukum-menyelam-ke-dalam-air-yang-kurang-daripada-dua-kolah, dicapai pada 23 Julai 2019. Ia menjelaskan pandangan Wahbah al-Zuhayli dari segi berat timbangan, 2 kolah bersamaan $195.113 \mathrm{~kg}$. Manakala dari segi sukatan, bersamaan 10 tin. Ada pendapat mengatakan 15 tin atau 270 liter.

9 'Ațiyyah, 'Abd al-Ḥasib Sanad, 'Anwā' al-Tațhīr wa Shurūṭuhu,' http://www. alukah.net/sharia/0/44555/, dicapai pada 14 April 2019.

10 Jamāl Șāliḥ, 'Wasā’il al-Tațhīr' (Risālah al-Majistir fī al-Sharī'ah al-Islāmiyyah, Jamī'ah al-Najah al-Wațāniyyah, Falașțīn, 2001).

11 Wahbah al-Zuhaylī, al-Figh al-Islāmī wa Adillatuh (Dimashq: Dār al-Fikr, 1989), 183-184. 
Dalam kajian mengenai piawaian teknikal yang digunakan dalam kaedah penyucian moden, Husām Alī Abdullah, menganalisis kaedah dan syarat penyucian najis berdasarkan mazhab Hanafi dengan merumuskan bahawa penggunaan mesin basuh moden menepati parameter purifikasi yang ditetapkan oleh fuqaha mazhab tersebut.

Kajian dijalankan oleh R. Yahaya et al. pula melihat proses basuhan mesin basuh dengan berlandaskan prinsip pembersihan yang diterima pakai dalam sektor perladangan. Berasaskan prinsip pembersihan untuk menghilangkan sifat toksin daripada 'food tuber' Dioscorea hispida (ubi gadong) sebelum ianya boleh digunakan dengan selamat, maka prinsip tersebut telah diaplikasikan bagi proses pembersihan dan penyucian pakaian yang bernajis menggunakan mesin basuh. Teknologi tersebut menjadikan produk makanan yang dihasilkan selamat untuk digunakan. Jika penggunaan kaedah ini berkemampuan menghilangkan sifat toksin yang wujud dalam D.hispida, maka secara tidak langsung menunjukkan najis yang ada pada sesuatu pakaian boleh dihilangkan melalui proses basuhan mesin basuh untuk menjadikan pakaian tersebut suci. ${ }^{12}$

Muhammad Hudzari Razali et al. pula telah menghasilkan satu mesin basuh berbentuk prototaip yang diubah suai bagi memastikan aspek kebersihan dan kesucian sebagaimana yang digariskan oleh fuqaha. Bersandarkan kepada asas keperluan untuk mengalirkan air secara berterusan kepada sesuatu benda yang bernajis bagi menghilangkan sifat najis tersebut. Hasil kajian ini adalah satu alternatif tanpa menafikan mesin basuh sedia ada di pasaran. Ianya sebagai satu langkah untuk memperkenalkan amalan terbaik yang mematuhi syarak melalui teknik pengaliran air secara berterusan dalam proses mod bilasan yang serentak untuk tujuan pengeringan. ${ }^{13}$

Permasalahan yang dibincangkan merupakan isu sejagat dihadapi oleh umat Islam seluruh dunia. Ia telah mengundangkan banyak respons sama ada dalam bentuk fatwa dan pandangan hukum peribadi daripada institusi fatwa di peringkat tempatan dan juga antarabangsa di samping ilmuan yang menjadi rujukan orang ramai.

12 Rizuwan Yahaya, Mohd. Huzari Razali, Basri Ibrahim, Mohd Shahril Othman, Noordin Asimi Mohd Noor, Hasbullah Muhammad \& Soran Jalal Abdullah, 'Conceptual Instrumentation of Washing Machine for Conformity to the Islamic Laws of Syarak,' Scientific Journal of Review, vol. 2, no. 6 (2013): 151-155.

13 Muhammad Hudzari Razali, Syazili Roslan, Muhammad Rahimi Osman, Muhammad Shahril Othman, Zulfakar Aspar \& Engku Fadzli Hasan Syed Abdullah, 'Development of Intelligence Technique in Syariah Compliance Washing Machine via PLC,' Journal of Artificial Intelligence, vol. 10, no. 2 (2017): 49-58 
Terdapat beberapa institusi fatwa dalam dan luar negara telah menerangkan hukumnya seperti Jabatan Mufti Wilayah Persekutuan dalam AL-KAFI LI ALFATAWI ${ }^{14}$ Darul Ifta' Mesir dalam fatwa bertarikh 10 April 2015 mengenai țaharat al-malābis al-najīsah idha wudi' 'at fi al-ghassalat al-utumatikiyyah, Lajnah al-Ifta, ${ }^{15}$ Darul Ifta' Jordan menjelaskannya dalam fatwa bernombor 2722 bertarikh 1 November 2012 mengenai hukm al-mā'al-mutațayir min almalābis al-najīsah athna' ghasliha, ${ }^{16}$ Islamic Affairs \& Charitable Activities Department, Emiriah Arab Bersatu (UAE) dalam fatwa mengenai hukm ghasl al-malābis allati biha najāsah ma'a al-țāhirah ${ }^{17}$ dan Darul Ifta Birmingham berkenaan bahawa pakaian yang terkena najis 'aynī jika basuh berulang kali dengan air mutlak dalam mesin basuh adalah bersih. ${ }^{18}$

Persoalan hukum di atas juga mendapat respon ramai para pendakwah dan ilmuan tempatan berkongsi pandangan dalam pelbagai medium ilmu seperti blog, Facebook, YouTube dan sebagainya, yang memberikan pandangan hukum masing-masing. ${ }^{19}$

14 Portal Rasmi Pejabat Mufti Wilayah Persekutuan, 'Menyucikan Pakaian Dengan Mesin Basuh,' http://www.muftiwp.gov.my/index.php/ms-my/perkhidmatan/ al-kafili-al-fatawi/1197-al-kafi-311-menyucikan-pakaian dengan-mesin-basuh, dicapai pada 15 April 2019. Lihat soalan 311 bertarikh 1 Julai 2016; Portal Rasmi Jabatan Kemajuan Islam Malaysia, 'Kemusykilan Agama,' http://kemusykilan. islam.gov.my/?data $=$ O2thdGVnb3JpX2RldGFpbDsxMzE7\&page=871, dicapai pada 15 April 2019.

15 Dār al-Iftā' al-Mișriyyah, 'Ṭahārah al-Malābis al-Najasah Idhā Wuḍi'at fī alGhasālāt al-Utūmātīkīh,' http://www.dar-alifta.gov.eg/ar/ViewResearch.aspx? $\mathrm{sec}=$ fatwa\&ID=151, dicapai pada 18 April 2019.

16 Al-Iftā', 'Hukm al-Mā' al-Mutațāyir min al-Malābis al-Najasah Athnā' Ghasalaha,' https://aliftaa.jo/Question.aspx?QuestionId=2722\#.XNDzpzAzYdU, dicapai pada 18 April 2019.

17 Islamic Affairs \& Cheritable Activities Department, https://services.iacad.gov.ae/ SmartPortal/fatwa/PublishedFatwa/Deatils/26018, dicapai pada 18 April 2019.

18 Darul Ifta, 'Washing Clothes via Washing Machine,' http://daruliftabirmingham. co.uk/washing-clothes-via-the-washing-machine/, dicapai pada 15 April 2019.

19 T.p., 'Hukum Guna Pakaian Dibasuh dengan Mesin Basuh Automatik,' Youtube, https://www.youtube.com/ watch?v=A0F29gZu5qA, dicapai pada 15 April 2019; Rozaimi Ramle, 'Hukum Menggunakan Mesin Basuh Yang Sama Dengan Non-Muslim?' https://www.facebook.com/DrRozaimiRamle/ posts/1523422311018597, dicapai pada 15 April 2019; T.p., 'Hukum Menggunakan Mesin Cuci Baju,' http://naaimahbtenaaim. blogspot.my/2017/09/ hukum-menggunakan-mesin-cuci-baju.html., dicapai pada 15 April 2019. 
Antara pengendali web luar berbahasa Arab yang aktif ialah Islamweb.net ${ }^{20}$ yang menekankan perbezaan antara basuhan pakaian bernajis hukmī dan 'aynī. Bagi basuhan najis 'aynī, kesan najis tersebut hendaklah disucikan sepenuhnya dengan yakin sekalipun sama dibasuh tangan ataupun dengan mesin basuh.

Berdasarkan sorotan di atas, kajian ini mendapati belum ditemui sebuah kajian yang mengaplikasikan kaedah sains forensik dalam pengujian kebersihan kesan najis yang menggunakan mesin basuh dan mesin dobi. Walaupun standard kebersihan yang ditetapkan oleh fuqaha ialah kenyahwujudan kesan zahir sesuatu najis, tidak bermakna syarak melarang kajian lebih terperinci seperti analisis DNA Forensik yang berupaya mengesan kewujudan atau kenyahwujudan molekul najis pada pakaian, jika hasil keputusannya dapat meyakinkan hati pengguna Muslim selain menolak perasaan was-was tentang kebersihan. Penggunaan kaedah analisis ini juga dapat membantu mengurangkan jurang perselisihan antara fuqaha masa kini berhubung isu kebersihan. Justeru, kajian ini amat diperlukan bagi mengukuhkan hukum kebersihan pakaian bernajis menggunakan teknologi semasa yang memudahkan kehidupan.

\section{HUKUM PEMBERSIHAN NAJIS}

Dari segi bahasa, perkataan najis atau dalam bahasa Arabnya najāsah bermaksud sesuatu yang kotor. Manakala dari segi istilah pula, ditakrifkan sebagai "sesuatu yang dianggap kotor dan mencegah sahnya solat tanpa ada hal yang meringankan". ${ }^{21}$ Dalam pengertian lebih jelas, para fuqaha bersepakat bahawa najis merupakan sebarang benda atau perkara yang dihukumkan syarak sebagai kotoran yang perlu dihilangkan untuk kesempurnaan ibadat kepada Allah SWT.

Secara umumnya, terdapat tiga kategori najis mengikut pandangan Shāfi'iyyah iaitu najis mukhaffafah, najis mutawașșitah dan najis mughallazah. Najis mukhaffafah hanya terdiri daripada air kencing kanak-kanak lelaki berusia kurang daripada dua tahun yang sumber pemakanannya hanya susu.

20 Islamweb.net, 'Fatwa,' http://fatwa.islamweb.net, dicapai pada 18 April 2019. Lihat siri penerangannya dalam http://fatwa.islamweb.net/fatwa/index.php?pa ge=showfatwa\&Option=FatwaId \&Id=177849), 174107, 174865, 171787 dan 176059., dicapai pada 18 April 2019.

21 Ibn Haytham, Shihāb al-Dīn Aḥmad Ibn Hajar, Tuhfat al-Muhtāj bi Sharh alMinhājj, vol. 1 (Qāhirah: Dār al-Hadīth, 2016), 134-135; al-Bujayrimī, Sulaymān Ibn 'Umar Ibn Muhammad, Tuḩah al-Habīb 'alā Sharh al-Khātib, vol. 1 (Bayrūt: Dār al-Fikr, 1995), 312; al-Rayyashī, Șāliḥ Ḥasan, al-Sharh al-Manhajī al-Mu 'āṣir li Alfāz al-Faqīh Abì Shujā' al-Shāfi 'c̄ (Bayrūt: Dār Ibn Ḥazm, 2013), 159-160. 
Najis mughallazah ialah kategori jenis berat, iaitu anjing dan babi serta derivatif kedua-duanya. Najis mutawașsitah ialah semua kategori najis selain dua kategori di atas. Ia terbahagi kepada dua jenis iaitu najis hukmiyyah dan najis 'ayniyyah. ${ }^{22}$

Umat Islam bertanggungjawab memastikan kebersihan (tahārah) diri daripada pelbagai kategori (mukhaffafah, mutawașșitah dan mughallazah) dan jenis najis (hissī, 'aynī, ma 'nawī dan hukmī). Al-Quran dan hadis menekankan kepentingan kebersihan pakaian sebagai satu pra syarat kesahihan solat. Kebersihan telah dianggap sempurna apabila tiga kesan najis seperti bau, rasa dan warna telah diyakini hilang. ${ }^{23}$

\section{PENGGUNAAN AIR MUTLAK}

Semua fuqaha dalam pelbagai mazhab bersepakat bahawa air mutlak adalah instrumen utama pembersihan daripada kotoran dan perkara-perkara yang dihukumkan najis oleh syarak. Mereka turut bersepakat bahawa penggunaan air mutlak adalah syarat sah untuk pembersihan pakaian daripada najis. ${ }^{24}$

22 al-Sharbīnī, Shams al-Dīn Muhammad Ibn Muhammad al-Khātị, Mughn̄̄ al-Muhtāj ilā Ma 'rifātī Ma'ān̄̄ Alfāz al-Minhāj, vol. 1, ed. 'Alī Muhammad Mu'awwad dan 'Ādil Ahmad al-Mawjūd (Bayrūt: Dār al-Kutub al-'Ilmiyyah, 1994), 239; al-Ramlī, Shams al-Dīn Muhammad Ibn Abī al-'Abbās Aḥmad Ibn Hamzah Ibn Shihāb al-Dīn, Nihāyah al-Muhtāj Ila Sharh al-Minhāj, vol. 1 (Bayrūt: Dār al-Kutub al-'Ilmiyyah, 2003), 251; al-Bujayrimī, Sulaymān Ibn 'Umar Ibn Muhammad, Tuhfah al-Habīb 'alā Sharh al-Khāṭib, vol. 1, 316.

23 al-Nawawī, Ab̄̄ Zakariyyā Mahy al-Dīn Ibn Sharf, Asnā al-Mațālib fì Sharh Rawụah al-Ṭālibīn (T.t.p: Dār al-Kutub al-'Ilmiyyah, t.t.), 19; al-Sharbīn̄i, Shams al-Dīn Muḥammad Ibn Muḥammad al-Khāțib, Mughnī al-Muhtāj ilā Ma rifāat̄̄ Ma 'ānī Alfāz al-Minhāj, vol. 1, 242; al-Dimyatī, Abī Bakr 'Uthmān Muhammad Shața' al-Bakrī, Hāshiyah I'ānah al-Ṭālibìn, vol. 1 (Bayrūt: Dār al-Fikr, 1997), 113.

24 al-Nawawī, Ab̄̄ Zakariyyā Maḥy al-Dīn Ibn Sharf, al-Majmū' Sharh alMuhadhdhab, vol. 1 (Bayrūt: Dār al-Fikr, t.t.), 616-617; Ibn 'Ābidīn, Muhammad Amīn, Radd al-Muhtār 'ala al-Durr al-Mukhtār (Bayrūt: Dār al-Fikr, 2000), 501; al-Ḥaț̣āa, Abī 'Abd Allāh Muḥammad Ibn Muḥammad Ibn 'Abd al-Raḥmān alMaghribī al-Ra'yanī, Mawāhib al-Jalīl li Sharh Mukhtașșar Khalīl, vol. 1, ed. Zakariyya 'Umayrat (Bayrūt: Dār al-Kutub al-'Ilmiyyah, 1995), 62; al-Sharbīn̄,, Shams al-Dīn Muhammad Ibn Muḥammad al-Khāṭib, Mughnī al-Muhtāj ilā Ma 'rifātī Ma 'ānī Alfāza al-Minhāj, vol. 1, 115-116; al-Bahūtī, Manșūr Ibn Yūnus Ibn Idrīs, Kashf al-Qinā' an Matn al-Iqnā', vol. 1, ed. Ibrāhim Aḥmad 'Abd alḤamīd (Riyāḍ: Dār Alam al-Kutub, 2003), 216. 
Cara penggunaan air adalah bergantung kepada kuantitinya sama ada banyak iaitu melebihi dua qullah ataupun sedikit iaitu kurang daripada jumlah tersebut. Menurut praktis pembersihan najis dalam mazhab Shāfi' $\overline{1}$, jika air yang digunakan itu banyak seperti air sungai yang mengalir, kesan najis dihukum hilang jika direndam (dicelup) di dalamnya dengan sekali celupan.

Namun jika kuantiti air kurang, terdapat beberapa perincian masalah yang perlu diperhatikan seperti berikut:

a) Pembersihan najis hukmī memadai dengan cara menjiruskan air mutlak pada tempat (mahal) terkenanya najis pada pakaian tersebut sehingga zat ('ayn) dan juga kesan rasa, warna dan rasa telah dibersihkan. ${ }^{25}$ Praktis ini adalah berpandukan beberapa hadis seperti berikut:

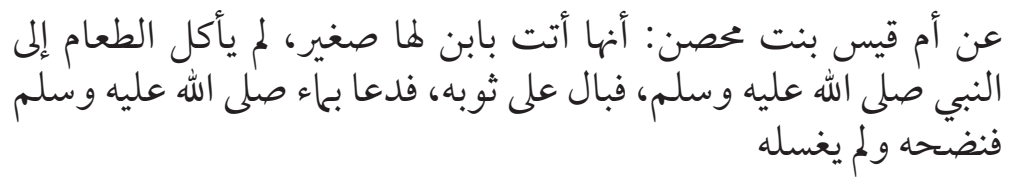

"Daripada Ummu Qays bint Mihsan membawa bayi lelaki kecilnya yang belum memakan makanan kepada Rasulullah, lalu dia kencing atas pakaian Baginda. Maka Baginda meminta air lalu menjiruskan ke atasnya (tempat terkena kencing) dan tidak membasuhnya." 26

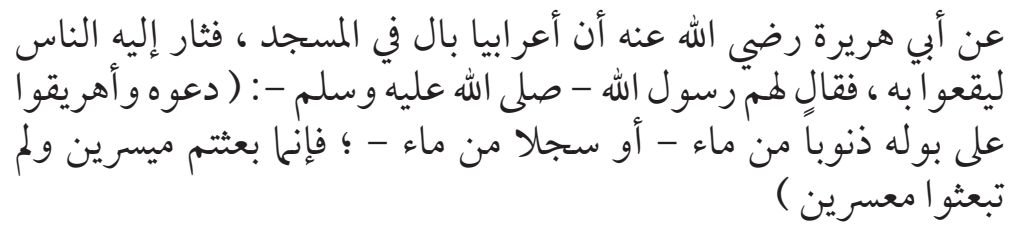

"Daripada Abi Hurayrah RA, seorang lelaki Badawi kencing dalam masjid, lalu orang ramai menyerbu ke arahnya agar dapat menangkapnya. Rasulullah SAW bersabda kepada mereka supaya membiarkannya dan menyuruh mereka menjirus beberapa cedokan air ke tempat kencingnya. Sesungguhnya

25 al-Nawawī, Abī Zakariyyā Maḥy al-Dīn Ibn Sharf, Raw ḍah al-Ṭālibīn wa 'Umdah al-Muftīn, vol. 1 (Bayrūt: al-Maktabah al-Islāmī, 1991), 28; al-Nawawī, Ab̄̄ Zakariyyā Maḥy al-Dīn Ibn Sharf, Asnā al-Mațāib fì Sharḥ Rawḍh al-Ṭālibìn, vol. $1,19$.

26 al-Bukhārī, Ab̄̄ 'Abd Allāh Muḥammad Ibn Ismā'il al-Ju'fī, Șah̄ịh al-Bukhārī, ed. Muhammad Zuhayr Ibn Nașīr (t.t.p.: Dār Ṭawq al-Najāh, 2001), 54, "Bāb Bawl al-Șibyān," no. hadis 223. 


\section{kalian diutuskan untuk mempermudahkan (urusan hidup dengan Islam) dan bukannya menyusahkan.” 27}

b) Jika najis 'ayn̄ (yang mempunyai zat boleh dilihat), wajib membersihkan terlebih dahulu bentuk dan juga kesan rasanya ( $\mathrm{a}^{\prime} \mathrm{m}$ ) walaupun sukar dihilangkan. Ini kerana kesan rasa yang berbaki, menunjukkan najis belum bersih sepenuhnya. Walau bagaimanapun, jika salah satu daripada bau (rih) atau warna (lawn) masih wujud kerana sukar dihilangkan, ia adalah dimaafkan. ${ }^{28}$

c) Mengenai jumlah (bilangan) basuhan, jika najis hukmi seperti air kencing yang telah kering dan tiada lagi kesannya seperti bau, cara pembersihannya memadai (wajib) dengan satu kali sahaja curahan (basuhan) air. Disunatkan membasuh dua atau tiga kali. Jika najis aini, zat najis dan semua kesannya yang boleh ditanggalkan dengan mudah, mesti dihilangkan sepenuhnya. ${ }^{29}$

Kuantiti air yang sedikit (kurang daripada dua kolah) akan menjadi mutanajjis jika pakaian bernajis dimasukkan ke dalamnya. Tindakan demikian akan menyebabkan pakaian tidak dihukum bersih kerana ciri kemutlakan air telah tercemar dengan najis. Air bernajis tidak dapat membersihkan kesan najis. ${ }^{30}$ Dalam situasi seperti ini, pakaian tersebut tidak dihukumkan bersih walaupun proses penyucian berlaku beberapa kali.

Justeru, fuqaha Shāfi'iyyah mensyaratkan agar air dicurahkan (murūr al$\left.m \bar{a}^{\prime}\right)$ ke atas pakaian atau bekas rendaman pakaian bagi mengelakkan air basuhan tidak menjadi mutanajjis. Keadaan di atas berbeza jika air yang

27 al-Bukhārī, Abī 'Abd Allāh Muḥammad Ibn Ismā'il al-Ju'fî, Ṣaḥīh al-Bukhārī, vol. 8, 30, "Bāb Qawl al-Nabī Yassirū," no. hadis 6128.

28 Najis al- 'ayn ialah benda najis yang dihukumkan najis pada zatnya seperti babi, anjing, tahi, air kencing dan darah. Mutanajjis pula ialah benda yang pada asalnya bersih tetapi menjadi bernajis disebabkan terkena najis al-ain. Lihat al-Nawawī, Abī Zakariyyā Maḥy al-Dīn Ibn Sharf, Rawḍh al-Ṭālibìn wa 'Umdah al-Muftīn, vol. 1, 28.

29 al-Nawawī, Abī Zakariyyā Maḥy al-Dīn Ibn Sharf, Rawḍh al-Ṭālibīn wa 'Umdah al-Muftīn, vol. 1, 28.

30 al-Sharbīnī, Shams al-Dīn Muhammad Ibn Muhammad al-Khāṭib, Mughnī alMuhtāoj ilā Ma 'rifātī Ma 'ānī Alfāz al-Minhāj, vol. 1, 242; al-Ramlī, Shams al-Dīn Muḥammad Ibn Abī al-'Abbās Aḥmad Ibn Hamzah Ibn Shihāb al-Dīn, Nihāyah al-Muhtājj Ila Sharḥ al-Minhāj, vol. 1, 260. 
sedikit dimasukkan (wurūd al-ma') ke atas tempat terkena najis kerana ciri kebersihan (tahüriyyah) dan kemutlakan air masih kekal. ${ }^{31}$

d) Namun fuqaha Hanafiyyah tidak membezakan antara memasukkan pakaian ke dalam air yang sedikit atau sebaliknya. Mengikut mereka, jika pakaian tersebut termasuk dalam jenis yang diserap air dan boleh diperah, kaedah basuhannya berbeza berdasarkan kesan najis. Jika kesan najis boleh dilihat (najāsah mar'iyyah), ia mesti dihilangkan dengan (beberapa kali) basuhan dan perahan sehingga kesannya hilang. Sekiranya kesan najis tidak boleh dilihat (najāsah ghayr mar'iyyah), pakaian tersebut hendaklah dibasuh (dicelup, dijirus atau dibilas) sebanyak tiga kali menggunakan air baharu dan memerah pakaian tersebut setiap kali dibasuh. Namun pada pandangan Hanafiyyah, amalan tersebut dibolehkan dan pakaian dihukum bersih dengan syarat dicelup atau dibilas sebanyak tiga menggunakan air baharu dan memerah pakaian tersebut selepas setiap kali bilasan. ${ }^{32}$

\section{BAHAN PEMBERSIH SELAIN AIR}

Para fuqaha berkhilaf mengenai keberkesanan pelbagai instrumen penyucian selain air, seperti istihālah, panahan cahaya matahari, pembakaran, seretan atas tanah yang bersih dan lain-lain cara yang dapat menghilangkan kesan najis.

Jumhur fuqaha daripada Shāfi'iyyah, Muhammad al-Ḥasan dan Zufar daripada Hanafiyyah berpendapat hanya air boleh digunakan untuk tujuan tersebut di samping amalan samak (dibagh) ke atas kulit dan perubahan (istihālah) arak kepada cuka yang terjadi dengan sendiri. ${ }^{33}$

31 al-Sharbīnī, Shams al-Dīn Muḥammad Ibn Muḥammad al-Khāṭib, Mughnī alMuhtāaj ilā Ma 'rifātī Ma 'ānī Alfāz al-Minhāj, vol. 1, 242; al-Ramlī, Shams al-Dīn Muhạmmad Ibn Abī al-'Abbās Aḥmad Ibn Hamzah Ibn Shihāb al-Dīn, Nihāyah al-Muḥtāj Ila Sharh al-Minhāj, vol. 1, 260.

32 Ibn 'Ābidīn, Muḥammad Amīn, Radd al-Muhtār 'ala al-Durr al-Mukhtār, vol. 1, 332; al-Kasān̄̄, Abū Bakr Ibn Mas'ūd al-Hanāfī, Badā' $i$ ' al-Ṣana 'i ' fì Tartīb al Sharā'i', vol. 1, ed. 'Alī Muḥammad Mu'awwad \& Ādil Aḥmad 'Abd al-Mawjūd (Bayrūt: Dār al-Kutub al-'Ilmiyyah, 2003), 451.

33 al-Nawawī, Abī Zakariyyā Maḥy al-Dīn Ibn Sharf, al-Majmū' Sharh alMuhadhdhab, vol. 1, 616-617; Ibn 'Ābidīn, Muhammad Amīn, Radd al-Muhtār 'ala al-Durr al-Mukhtār, vol. 1, 510; al-Ḥațāō, Abī 'Abd Allāh Muhammad Ibn Muḥammad Ibn 'Abd al-Raḥmān al-Maghribī al-Ra'yan̄̄, Mawāhib al-Jalīl li Sharḥ Mukhtașșar Khalīl, vol. 1, 120; al-Bahūtī, Manșūr Ibn Yūnus Ibn Idrīs, Kashf al-Qinā' an Matn al-Iqnā', vol. 1, 216. 
Kebanyakan Hanafiyyah ${ }^{34}$ dan Ibn Taymiyyah ${ }^{35}$ memperluaskan praktik penyucian ke atas setiap sesuatu yang berkesan membuang kesan najis dan kotoran adalah diterima sebagai muțhhirāt yang sah. Mereka memperluaskan fungsi istihālah kepada keupayaan cahaya matahari, tanah, sabun dan semua bahan pencuci yang mampu menghilangkan najis. Pandangan ini ditarjihkan oleh al-Ṣan'ānī ${ }^{36}$ dan al-Shawkānī. ${ }^{37}$

Pada pandangan kedua ini apabila sesuatu najis dapat dihilangkan dengan pelbagai cara maka hukum kenajisannya turut hilang. Ini kerana hukum berkait dengan sesuatu sebab ('illah). Apabila sebabnya telah tiada, maka hukum tersebut akan berubah. Walau bagaimanapun, penggunaan bahan makanan dan minuman untuk menghilangkan najis tanpa sebarang keperluan (häjah) adalah diharamkan kerana hal demikian termasuk perbuatan memusnahkan harta. Bahan-bahan tersebut juga haram dijadikan bahan untuk istinjak. ${ }^{38}$

\section{Penggunaan Mesin Basuh dan Dobi Layan Diri}

Pada masa kini, penggunaan mesin basuh dan dobi layan diri merupakan kemudahan yang dimanfaatkan oleh semua pengguna termasuk umat Islam terutama mereka yang tinggal di kawasan bandar dan menginap di apartment bertingkat yang berjauhan pula daripada sungai, laut, tasik dan sumber air.

Mesin basuh sudah menjadi suatu keperluan asas dalam rumah, selain dapat menjimatkan masa dan tenaga, berbanding basuhan tangan secara tradisional seperti pada zaman dahulu. Teknologi basuhan yang dimanfaatkan sama ada di rumah ataupun di kedai dobi termasuk layan diri (self service) itu menggunakan air dalam proses cuciannya bersama bahan pencuci (detergent) dan pelembut (softener) pakaian.

34 Ibn 'Ābidīn, Muhammad Amīn, Radd al-Muhtār 'ala al-Durr al-Mukhtār, vol. 1, 509; Ibn Nujaym, Zayn al-Dīn Ibn Ibrāhīm, al-Baḥr al-Rā'iq Sharh Kanz alDaqū'iq, vol. 1 (Bayrūt: Dār al-Kitāb al-Islāmī, t.t.), 233.

35 Ibn Taymiyyah, Abī 'Abbās Taqī al-Dīn Ahmmad Ibn 'Abd al-Halīm, Majmū ' alFatawā, vol. 21, ed. 'Abd al-Raḥmān Ibn Muḥammad dan Muḥammad Ibn 'Abd al-Raḥmān (al-Madīnah al-Munawwarah: Mujamma' al-Mālik Fahd li Tibā'ah alMushaf al-Sharif, 2004), 475.

36 al-Ṣan‘ānī, Muḥammad Ibn Ismā‘īl al-Kahlanī Abū Ibrāhim, 'Izz al-Dīn, Subl alSalām Sharḥ Bulūgh al-Maram (Qāhirah: Dār al-Ḥadīth, t.t.), 41.

37 al-Shawkānī, Muhammad Ibn 'Alī Ibn Muhammad, Nayl al-Awțār, vol. 3 ed. 'Ișām al-Dīn al-Șabābuṭ̂ি (Qāhirah: Dār al-Ḥadīth, 1993), 85.

38 Ibn Taymiyyah, Abī 'Abbās Taqī al-Dīn Aḥmad Ibn 'Abd al-Ḥalīm, Majmū' alFatawā, vol. 1, 475. 
Terdapat dua jenis mesin basuh automatik, iaitu muatan atas dan muatan hadapan. Mesin basuh muatan atas menempatkan pakaian yang dimuatkan melalui penutup di sebelah atas ke dalam tab yang disusun menegak serta mempunyai pemutar (pulsator) pada bahagian dasarnya. Penggunaan mesin basuh muatan atas ini amat popular di seluruh negara termasuk Malaysia.

\section{METODOLOGI}

Kajian ini sebahagian besarnya bersifat kualitatif dan menggunakan kaedah Analisis Profil DNA Forensik. Semua data dan maklumat mengenai țahārah dan instrumen pembersihan najis diteliti daripada buku-buku fiqh dan hadishadis hukum yang berautoriti sama ada karya klasik atau kontemporari, tesis, disertasi, artikel, kertas kerja dan sebagainya. Sementara proses pengendalian sampel kajian dan langkah-langkah pembersihan menggunakan mesin basuh dan dobi untuk menguji kemampuannya menghilangkan kotoran dan najis, berpandukan kepada khidmat nasihat beberapa orang pakar sains forensik di Jabatan Kimia Cawangan Pulau Pinang.

Semua data kajian dibahagikan kepada tiga kategori pengumpulan. Pertama, konsep bersuci (țhārah) dalam kes-kes pembersihan najis. Kedua, alat pembersihan najis berdasarkan pandangan fuqaha Shāfi'iyyah, di samping mengambil kira pandangan fuqaha mazhab lain. Beberapa pandangan sarjana Islam semasa turut diberikan perhatian. Ketiga, analisis keberkesanan teknologi basuhan mesin basuh dalam menghilangkan kotoran dan najis.

\section{Sampel Kajian}

Sebanyak tiga sampel najis iaitu darah, air kencing dan najis bayi telah digunakan pada pakaian. Sampel-sampel tersebut akan diletakkan pada pakaian yang akan dicuci menggunakan dua teknik basuhan, iaitu mesin basuh automatik dan perkhidmatan cucian dobi layan diri.

Dalam analisis zat/unsur najis, kajian ini menggunakan kaedah analisis profil DNA bagi menentukan kehadiran zat/unsur najis iaitu darah, air kencing dan najis bayi pada pakaian sebelum dan selepas basuhan. Teknik analisis DNA adalah teknik untuk mengesan kehadiran DNA yang diwakili oleh zat/ unsur najis di dalam sampel kajian. Zat/unsur najis ini adalah terdiri dari bahan kumbahan dan juga sel-sel dari manusia. Namun, antara ketiga-tiga zat/ unsur najis ini, kandungan DNA yang mengandungi sel manusia paling banyak terdapat pada sampel darah. 
Kajian ini memilih untuk menggunakan jenis pakaian yang biasa digunakan seharian iaitu fabrik kapas (cotton) yang berpoket dan fabrik yang lebih tebal seperti denim (jeans). Sampel pakaian akan disapukan najis dan bahagian yang terkena najis akan ditandakan sebelum memulakan proses basuhan. Sebahagian daripada pakaian yang disapukan najis akan digunting dan dikeringkan di tempat yang teduh bagi tujuan sampel kawalan (control sample) kehadiran najis pada pakaian. Sampel kawalan (control sample) yang kering akan disimpan di dalam sampul sebelum dihantar ke makmal Jabatan Kimia. Manakala proses pembersihan semua sampel kajian dikendalikan secara terkawal di Makmal Kimia, Fakulti Kejuruteraan kimia Universiti Teknologi MARA Cawangan Pulau Pinang.

\section{Kaedah Basuhan}

\section{Kaedah Basuhan Mesin Basuh}

Dalam kajian ini, model mesin basuh muatan atas yang digunakan adalah Sharp 8 kg Fully Auto Washing Machine Washer Es818x yang menggunakan teknologi S Pulsator dan juga Fuzzy Control. Teknologi S-Pulsator ini melibatkan pergerakan air secara tiga dimensi yang boleh meningkatkan lagi kelarutan bahan pencuci (detergent) serta menghilangkan kotoran dengan lebih berkesan. Bagi teknologi Fuzzy Control pula, beban atau berat serta jenis kain akan ditentukan oleh pengesan (sensor) secara automatik. Untuk muatan depan, model mesin basuh yang akan digunakan adalah Electrolux 5th- Generation W5130S yang terdapat di kedai dobi layan diri berdekatan UiTM Cawangan Pulau Pinang.

Manakala, bahan pencuci asas yang akan digunakan adalah Cecair Cucian Pekat Dynamo. Cecair Cucian Pekat Dynamo ini dipilih kerana ia tidak mengandungi fosfat yang menjadikan Dynamo mesra alam sekitar. Selain daripada itu, Cecair Cucian Pekat 29 Dynamo memberikan prestasi pembersihan berkuasa yang pekat dan semua surfactant dalam Dynamo mudah terbiodegradasikan. Terbiodegradasikan bermakna cecair cucian pekat ini bukan sahaja selamat untuk pakaian malahan untuk alam sekitar juga. Keterlarutan Cecair Cucian Pekat Dynamo ini yang mudah akan memberikan pencucian yang lebih berkesan dan pakaian yang lebih bersih. Dalam basuhan menggunakan mesin basuh, pakaian bernajis tersebut akan dibasuh bersama pakaian lain yang tidak bernajis menggunakan mod ketetapan piawai (standard setting). Sampel pakaian yang telah dibasuh dan kering dilabelkan dalam bekas khas dan dimasukkan dalam kotak yang dilekatkan dengan selotep. Selepas 
itu, kotak sampel tersebut dihantar ke makmal Jabatan Kimia Cawangan Pulau Pinang untuk dianalisis.

\section{Kaedah Basuhan Mesin Dobi}

Bagi kaedah basuhan menggunakan dobi layan diri, cara basuhannya telah diprogramkan dalam sistem operasi mesin tersebut dan berbeza daripada kaedah mesin basuh muatan atas. Oleh yang demikian, proses pengesanan status kesuciannya akan dibuat dengan mengambil sampel cebisan pakaian asal terkena najis sebagai sampel kawalan (control sample) dan pakaian yang bercampur dengannya. Masa yang diambil untuk proses basuhan adalah selama 40 minit yang melibatkan 130 liter air berbanding dengan mesin basuh muatan atas yang menggunakan hanya 63 liter air, manakala proses pengeringan adalah selama 25 minit.

Selepas proses basuhan dan pengeringan menggunakan mesin dobi, sampel pakaian akan diambil dan disimpan di dalam petri dish plastik. Sampel tersebut akan diuji kewujudan sisa molekul najis sama ada positif atau negatif.

\section{Kaedah Pengesanan Kewujudan Najis Pada Pakaian}

Pengujian ke atas sampel kotoran darah adalah menggunakan dua kaedah, iaitu Kestle-Meyer Test (KM Test) dan Profil DNA Forensik. Manakala sampel air kencing dan najis bayi dianalisa dengan hanya menggunakan kaedah Profil DNA Forensik. Sampel-sampel tersebut akan diuji bagi mengesan kewujudan atau kenyahwujudan molekul DNAnya selepas basuhan menggunakan mesin basuh muatan atas dan mesin dobi layan diri.

\section{Kestle-Meyer Test}

Bagi menentukan kehadiran darah pada pakaian, ujian saringan (screening test) telah dijalankan ke atas sampel dengan menggunakan kaedah Kestle-Meyer Test. ${ }^{39}$ Kestle-Meyer Test adalah kaedah ujian forensik bagi menentukan kehadiran darah di mana bahan kimia fenolftalein telah digunakan. Fenolftalein adalah cecair yang tidak berwarna dan akan bertukar kepada warna merah jambu setelah dioksidakan oleh haemoglobin dan hidrogen peroksida. Kajian terhadap kehadiran najis darah telah dijalankan menggunakan blotting paper yang disapu ke atas permukaan sampel kain yang mempunyai najis darah.

39 Glaister, J., 'The Kastle-Meyer Test for the Detection of Blood: Considered from the Medico-Legal Aspect,' British Medical Journal, vol. 1 (1926): 650-652. 
Kemudian, setitis cecair etanol serta fenolftalein dititiskan ke atas kertas blotting tadi dan diikuti setitis hydrogen peroksida ke atas blotting paper yang sama. Jika warna berubah kepada merah jambu dalam masa 10 saat, sampel adalah positif mengandungi darah. Jika blotting paper tidak bertukar warna selepas 10 saat, sampel adalah negatif iaitu tidak mengandungi darah. Langkah yang sama telah dijalankan ke atas sampel kain yang mengandungi darah yang telah dibasuh menggunakan mesin dobi layan diri dan mesin basuh muatan atas.

\section{Kaedah Analisis Profil DNA Forensik}

Kajian ini telah menggunakan bantuan kaedah analisis profil DNA Forensik ke atas tiga sampel kotoran, iaitu darah, air kencing dan najis bayi. Sampelsampel tersebut telah diuji bagi mengesahkan kewujudan atau kenyahwujudan DNAnya selepas basuhan menggunakan mesin basuh muatan atas dan mesin dobi layan diri. Analisis profil DNA forensik ini telah dijalankan di Bahagian Forensik, Jabatan Kimia Malaysia Negeri Pulau Pinang mengikut protokol piawai bagi analisis profil DNA forensik dan dikendalikan oleh kakitangan staf makmal.

Teknik profil DNA forensik dalam kajian ini terdiri daripada empat langkah, iaitu pengekstrakan DNA (extraction), pengiraan (quantitation), penggandaan (amplification) dan pengasingan dan penganalisaan macromolecule DNA (electrophoresis).

\section{a) Pengekstrakan (Extraction)}

Sampel pakaian telah digunting dari bahagian yang mengandungi najis kepada cebisan kecil bagi proses pengekstrakan DNA. Kemudian, pengasingan najis dari media pakaian dilakukan dengan merendam cebisan sampel pakaian mengandungi najis ke dalam 500 larutan lysis (lysis buffer $[10 \mathrm{mM}$ Tris $(\mathrm{pH}$ 8.0), 10 mM EDTA, and 2.0\% SDS]) bagi tujuan untuk memecahkan sel hidup yang terdapat pada sampel kain bagi tujuan mendapatkan bahagian DNA sel. Kemudian, 5-10 $\mu \mathrm{L} 20 \mathrm{mg} / \mathrm{ml}$ enzim proteinase $\mathrm{K}$ ditambah ke dalam rendaman sampel. Sampel kemudian dibiarkan selama 1 hingga 3 jam pada suhu $56^{\circ} \mathrm{C}$ sehingga semua tisu sel larut. DNA diekstrak dari sampel dengan menggunakan campuran larutan fenol:klorofom: alcohol isoamil (25:24:1, v/v) dan campuran tersebut disekatakan dengan menggoncang tiub dengan membalik-balikkan tiub tersebut secara perlahan-lahan selama 3 minit. Sampel kemudiannya diempar (Eppendorf 5415; Hamburg, Germany) selama 10 minit pada $10,000 \mathrm{~g}\left(4^{\circ} \mathrm{C}\right)$. Lapisan atas (akueus) kemudian diasingkan ke dalam pengempar mikro lain yang telah disteril. $10 \mu \mathrm{l}$ enzim RNase A $(10 \mathrm{mg} / \mathrm{ml}$; 
Fermentas, Thermo Scientific, Germany) ditambah dan kemudian dibiarkan selama 30 minit pada suhu $37^{\circ} \mathrm{C}$. $10 \mu$ l larutan kloroform: alcohol isoamil ditambah dan diemparkan sekali lagi pada 10,000 g selama 10 minit pada suhu $4{ }^{\circ} \mathrm{C}$. Lapisan atas (akueus) diasingkan ke tiub pengempar mikro yang baru dan $20 \mu 1$ isopropanol (Merck, Whitehouse Station, NJ, USA) ditambah bersama dengan $2 \mu \mathrm{L}$ natrium asetat (3M) dan disejukkan pada suhu $-20^{\circ} \mathrm{C}$ bagi tujuan pemendakan. Selepas 1 jam, sampel diempar pada $10,000 \mathrm{~g}\left(4^{\circ} \mathrm{C}\right)$ selama 10 minit. Kemudian bahan cecair bahagian atas selepas pemendakan (supernatant) dituang dan diasingkan. $250 \mu 170 \%$ etanol (Merck) ditambah ke dalam tiub untuk melarutkan mendakan. Campuran ini kemudiannya diempar pada 10,000 g selama 10 min dan lapisan cecair bahagian atas mendakan dituang secara perlahan. Mendakan kemudiannya dikeringkan di bawah arus udara laminar (laminar air flow) dan disimpan dalam larutan 10 tris- $\mathrm{HCl}, 1$ mM EDTA, pH 7.6 (TE) larutan penimbal dan dibekukan pada suhu $-20^{\circ} \mathrm{C}$ untuk penyimpanan bagi proses yang seterusnya.

\section{b) Langkah 2: Pengiraan DNA (DNA Quantitation)}

Pengiraan DNA telah dilakukan bagi memastikan DNA yang diekstrak dari sampel mengandungi DNA manusia dan bukan dari sumber yang lain seperti bakteria. Selain itu, tujuan utama pengiraan DNA adalah untuk menentukan kesuaian jumlah DNA yang akan digandakan melalui PCR-STR. Kualiti dan kuantiti DNA yang diekstrak telah dianalisa.

\section{c) Langkah 3: Penggandaan DNA (Amplification)}

Penggandaan DNA telah dilakukan menggunakan teknik Polymerase Chain Reaction-Short Tendem Repeat (PCR-STR). SRT merupakan kaedah yang dilakukan bagi membezakan loki tertentu dari DNA. Melalui proses ini, DNA yang telah diekstrak akan digandakan bagi memastikan jumlah segmen DNA yang diperlukan adalah mencukupi bagi kajian selanjutnya.

\section{d) Langkah 4: Pengasingan dan Penganalisaan DNA Makromolekul (Elektrolisis Rerambut)}

Selepas gandaan DNA dilakukan menggunakan PCR, campuran DNA yang telah digandakan akan diasingkan bagi mengenalpasti dan membezakan molekul-molekul yang terdapat di dalam sampel. Pengasingan cebisan DNA (DNA fragment) adalah melalui proses yang dinamakan elektrolisis rerambut. Teknik ini menggunakan 3500XL Genetic Analyzer yang menggunapakai 
caj positif dan negatif dimana DNA molekul yang negative akan masuk ke rerambut dan berpindah ke anod positif di hujung rerambut yang bertentangan. Melalui proses ini, DNA diasingkan berdasarkan saiz DNA molekul.

Langkah yang sama telah-dilakukan bagi setiap sampel kain mengandungi najis tahi, air kencing dan darah. Seterusnya kandungan DNA bagi setiap sampel dibandingkan di antara sampel control positif dan juga sampel najis bagi setiap basuhan. Profil DNA yang mengandungi DNA kurang dari $0.2 \mathrm{ng}$ dikira lemah dan tidak memberi nilai yang penting. ${ }^{40}$

\section{ANALISIS DAN DAPATAN}

\section{Keputusan Pengujian Saringan Kestle Meyer Test (KM-Test)}

Ujian saringan Kestle-Meyer (KM-Test) telah dilakukan ke atas sampel pakaian yang mengandungi darah. Bagi sampel kawalan positif, iaitu pakaian yang mengandungi darah, perubahan warna pada blotting paper telah diperhatikan dan warna merah jambu telah dikesan menunjukkan kesan positif kehadiran darah pada sampel kain. Bagi sampel kain selepas basuhan, kedua-dua sampel menunjukkan kesan negatif kehadiran darah pada pakaian di mana tiada perubahan warna telah dikesan pada blotting paper setelah dititik dengan titisan cecair etanol, fenolftalein dan hidrogen peroksida. Melalui ujian saringan ini, telah disimpulkan bahawa kesan darah telah hilang setelah basuhan dilakukan terhadap sampel kain melalui kedua-dua kaedah, iaitu mesin basuh muatan atas dan mesin dobi layan diri.

\section{Keputusan Analisis Profil DNA}

Jumlah DNA yang dikesan pada sampel pakaian mengandungi darah, air kencing dan najis sebelum dan selepas basuhan dobi dan mesin basuh muatan atas adalah seperti di dalam jadual berikut:

40 Budowle B, Eisenberg AJ, van Daal A, 'Validity of Low Copy Number Typing and Applications to Forensic Science,' Croatian Medical Journal, vol. 50, no. 3 (2009): 207-217; Gill P, Whitaker J, Flaxman C, Brown N, Buckleton J, ‘An Investigation of the Rigor of Interpretation Rules for STRs Derived from Less Than 100 pg of DNA,' Forensic Science International, vol. 112, no. 1 (2000): 17 40 . 
Jadual 1: Keputusan Analisis DNA pada Tiga Sampel Kajian

\begin{tabular}{|c|c|c|c|c|c|c|}
\hline Sampel & $\begin{array}{c}\text { Darah A } \\
(\mathrm{ng} / \mu \mathrm{l})\end{array}$ & $\begin{array}{c}\text { Darah B } \\
(\mathrm{ng} / \mu \mathrm{l})\end{array}$ & $\begin{array}{c}\text { Air } \\
\text { kencing A } \\
(\mathrm{ng} / \mu \mathrm{l})\end{array}$ & $\begin{array}{c}\text { Air } \\
\text { kencing } \\
\mathrm{B}(\mathrm{ng} / \mu \mathrm{l})\end{array}$ & $\begin{array}{l}\text { Najis A } \\
(\mathrm{ng} / \mu \mathrm{l})\end{array}$ & $\begin{array}{l}\text { Najis B } \\
(\mathrm{ng} / \mu \mathrm{l})\end{array}$ \\
\hline Negatif sampel & TD & TD & TD & TD & TD & TD \\
\hline Positif sampel & 44.80 & 65.00 & TD & TD & TD & TD \\
\hline $\begin{array}{l}\text { Sampel selepas } \\
\text { basuhan dobi }\end{array}$ & 1.78 & 3.28 & TD & TD & TD & TD \\
\hline $\begin{array}{l}\text { Sampel selepas } \\
\text { basuhan mesin }\end{array}$ & 3.28 & 1.11 & 0.09 & TD & TD & TD \\
\hline
\end{tabular}

*TD: Tidak dikesan

Sumber: Laporan Pemeriksaan dan Análisis Ekshibit, Pusat Rujukan Analisis DNA Forensik Wilayah Utara, 2019

Berdasarkan Jadual 1, kehadiran najis pada sampel darah dikesan pada 44.80 dan $65.00 \mathrm{ng} / \mu 1$ pada sampel pakaian yang mengandungi darah sebelum melalui proses basuhan. Setelah melalui basuhan dobi, hanya $3.9 \%$ (1.78 ng/ $\mu 1)$ dan $5.0 \%$ (3.28 ng/ $\mu \mathrm{l})$ sampel DNA darah dikesan pada sampel darah A dan B. Manakala bagi sampel pakaian yang telah melalui basuhan mesin basuh muatan atas, terdapat 7.3\% (3.28 ng/ $\mu \mathrm{l})$ dan $1.7 \%(1.11 \mathrm{ng} / \mu \mathrm{l})$ sampel DNA dari sampel darah yang masih dikesan pada sampel pakaian. Hal ini menunjukkan, basuhan mesin basuh muatan atas dan dobi mampu merosakkan sebahagian besar DNA dengan memecahkan rantaian DNA dan bahan najis iaitu darah daripada sampel pakaian yang dibasuh.

Namun begitu, bagi kesemua sampel najis dan air kencing, DNA analisis menunjukkan bacaan $0.00 \mathrm{ng} / \mu \mathrm{l}$ iaitu tidak dikesan (TD) bagi semua sampel sebelum dan selepas basuhan. Berdasarkan nilai yang telah diperolehi, profil DNA yang mengandungi DNA kurang dari 0.2 nanogram dikira lemah dan tidak memberi nilai yang penting. Secara amnya, jumlah salinan DNA yang dikesan kurang daripada $0.2 \mathrm{ng}$, iaitu di bawah limit yang ditetapkan, memberi impak kepada ketidaktepatan interpretasi dapatan. ${ }^{41}$ DNA adalah asas bahan hidup pada setiap manusia, namun, najis dan air kencing mengandungi DNA dalam kuantiti yang mínimum kerana kedua-dua bahan ini terdiri daripada bahan kumuh yang dan juga DNA yang sudah rosak.

41 Budowle B, Eisenberg AJ, van Daal A, 'Validity of Low Copy Number Typing and Applications to Forensic Science,' 207-217. 
Dalam kajian ini, beberapa kekangan dalam penggunaan DNA analisis dalam penentuan kehadiran najis telah dikawal dengan baik seperti yang berikut:

a) Radiasi UV melalui cahaya matahari secara langsung boleh menyebabkan berlakunya cross-link antara nukleotida thymine molekul DNA yang seterusnya menghalang tindakan enzim polymerase semasa PCR. Oleh itu, sampel kain perlu di jemur di tempat teduh setelah dibasuh bagi mengelakkan kerosakan DNA. ${ }^{42}$

b) Sampel kain perlu di analisa dengan segera bagi mengelakkan kerosakan DNA yang berpunca dari enzim dan proses kimia semulajadi.

c) Sampel perlu dijalankan dengan teliti bagi mengelakkan berlakunya kontaminasi DNA.

\section{Metod Basuhan Sampel Kajian Menepati Kaedah Pembersihan Najis dalam Mazhab Shāfi'ī}

Penggunaan tiga sampel kajian iaitu darah, najis bayi dan air kencing mencakupi kategori najis mutawașsitah yang merupakan kategori najis terbanyak berlaku kepada orang ramai. Berbanding najis mukhaffah dan mughallazah, tiada sampel digunakan dalam kajian ini memandangkan cara pembersihannya berbeza daripada perincian cara pembersihan najis mutawașsițh.

Najis mukhaffah dalam mazhab Shāfi'ī hanya terdiri daripada air kencing kanak-kanak berusia dua tahun ke bawah dan mughallazah pula adalah babi, anjing dan spesis keturunannya. Najis mukhaffafah memadai dihilangkan dengan percikan air pada tempat terkena najis sahaja. Sementara najis mughallazah dihilangkan dengan tujuh kali basuhan termasuk satu kali air tanah.

Metode basuhan semua sampel tersebut yang menggunakan mesin basuh dan dobi layan diri adalah menepati dua kaedah basuhan yang disarankan oleh fuqaha Shāfi'iyyah seperti berikut:

a) Penggunaan air mutlak yang bersih walaupun kurang daripada dua kolah

b) Berlakunya proses kemasukan air (murur al-mā') ke dalam pakaian yang dimasukkan lebih awal dalam drum mesin basuh dan mesin dobi, bukan sebaliknya.

42 John M. Butler, Advanced Topics in Forensic DNA Typing: Methodology (USA: National Institute of Standads and Technology Gaithersburg, Maryland, 2012), $29-47$. 
c) Terbukti berlakunya bilangan ( $\mathrm{adad}$ ) basuhan air beberapa kali untuk menghilangkan kesan najis. Pertukaran air basuhan pertama akan dikeluarkan sebelum air baharu dimasukkan bagi putaran kali kedua.

c) Pakaian telah dikeringkan secara putaran (spinning) setelah selesai basuhan berdasarkan mod yang ditetapkan pada kedua-dua mesin. Proses putaran ini menepati kaedah perahan (i'sar) pakaian yang dihukumkan sunat oleh Shāfi'iyyah dan wajib menurut Hanafiyyah.

d) Dari segi pengesanan zat najis dan jenis kesannya, didapati;

i) Kesan najis iaitu bau, warna dan rasa telah hilang sepenuhnya.

ii) Kewujudan kesan warna yang masih samar-samar disebabkan kesukaran menghilangkannya dimaafkan oleh syarak atas faktor mashaqqah.

Setiap pakaian yang telah hilang semua kesan najis khususnya kategori mutawașițh adalah dihukumkan bersih sekiranya semua kesan tersebut dapat dihilangkan dengan mudah. Jika sukar dihilangkan selepas dibasuh dengan sabun (contoh) seperti kesan darah, pakaian tersebut dihukum bersih dengan dimaafkan (diberikan kelonggaran) pada kesan yang berbekas.

\section{Keupayaan Mesin Basuh dan Dobi Menghilangkan Najis}

Kajian ini turut mendapati basuhan mesin basuh dan dobi layan diri mampu menghilangkan ketiga-tiga unsur najis daripada pakaian. Berdasarkan kaedah screening menggunakan Kastle-Meyer test (KM Test) iaitu hasil pengesanan peringkat awal sesuatu unsur najis mendapati kewujudan najis pada sampel darah yang dibasuh adalah negatif berbanding kesan positif yang terdapat pada sampel kawalan (control sample) awal. Keputusan sampel darah diaplikasikan pada sampel air kencing dan tahi kerana kesannya lebih kuat berbanding kedua-dua sampel tersebut yang menjadi bahan kumuhan yang tidak mengandungi banyak DNA. Jika dilihat pada standard kebersihan dalam hukum fiqh, keputusan negatif tersebut sudah memadai untuk mengukuhkan kebersihan pakaian yang mengandungi tiga sampel najis.

Namun selepas dilanjutkan pada pengujian mengikut kaedah Polymerase Chain Reaction Short Tandem Repeat (PCR-STR) untuk analisis DNA pula, keputusan menunjukkan bahawa sebelum dibasuh, kehadiran najis pada sampel kawalan (control sample) darah yang dikesan pada 44.80 (sampel A) dan $65.00 \mathrm{ng} / \mu \mathrm{l}$ (sampel B), manakala selepas dibasuh, ia adalah seperti berikut:

a) Basuhan dobi: hanya tinggal $1.78 \mathrm{ng} / \mu \mathrm{l}$ dan $3.28 \mathrm{ng} / \mu \mathrm{l}$ pada sampel A dan B.

b) Basuhan mesin basuh, hanya terdapat $3.28 \mathrm{ng} / \mu 1$ pada sampel A dan 1.11 ng/ $\mu$ l pada sampel B. 
Keputusan ini menunjukkan, basuhan mesin basuh dan dobi mampu menyahkan DNA serta bahan najis iaitu darah. Namun, kewujudan kuantiti kecil kesan darah yang ditemui adalah berpunca daripada faktor-faktor seperti yang berikut;

a) Pengesanan darah didapati daripada nukleus yang terpecah daripada molekul darah yang telah terurai (hilang) tetapi masih melekat di dalam benang pakaian yang dibasuh.

b) Ketebalan kuantiti sampel darah $(2 \mathrm{ml})$ yang diletakkan pada pakaian dan dibiarkan kering selama 24 jam. Keadaan berbeza dengan dengan basuhan sebenar oleh pengguna yang akan membersihkan kesan darah (seperti darah haid dan istiḥa dah) terlebih dahulu atau kuantiti darah yang terkena itu sedikit.

Sehubungan perkara di atas, dinyatakan bahawa pengesanan kesan nukleus darah tersebut adalah tidak signifikan ataupun dianggap tidak wujud jika berpandukan piawaian hukum țahärah yang menekankan kewujudan unsur fizikal najis iaitu warna, bau dan rasa.

Kenyahwujudan najis yang dibuktikan secara saintifik melalui kaedah screening KM Test dan analisis profil DNA PCR-STR sangat kukuh untuk menolak spekulasi pengguna bahawa unsur najis masih wujud pada pakaian dan lantaran itu, basuhan pakaian perlu melalui banyak pengulangan proses murur al-mā' sehingga najis diyakini telah hilang. Pengulangan basuhan merupakan suatu mashaqqah kepada pengguna kerana kesan najis telah terbukti hilang sebelum itu. Ini bakal membebankan majoriti pengguna Muslim yang kebiasaannya menggunakan mod basuhan standard (default) yang ditetapkan oleh mesin basuh automatik.

\section{KESIMPULAN}

Penjagaan kebersihan amat dititikberatkan dalam hukum ibadat kerana seseorang hamba perlu menjaga adab dengan Allah SWT yang sifatnya cantik (jamīl) dan indah (tayyib). Kebersihan diri, pakaian dan semua lingkungan kehidupan bagi setiap individu Muslim mencerminkan kesungguhan agama Islam menjaminkan kehidupan yang sihat dan jauh daripada penyakit yang berpunca daripada kotoran dan najis.

Berpandukan kefahaman terhadap sumber al-Quran dan sunnah Nabi SAW, para fuqaha khususnya Shāfi'iyyah telah memperincikan kaedah pembersihan najis dan kotoran menggunakan pelbagai instrumen khususnya air bersih (mutlak) dan bahan-bahan lain yang diyakini membersihkan najis (muțahhirāt) seperti sabun, serta, samak dan seumpamanya. Kaedah-kaedah 
yang disarankan adalah berdasarkan ijtihad dan kajian setempat pada zaman masing-masing, berdasarkan realiti keupayaan mengesan serta kemampuan menghilangkan tiga unsur najis, iaitu bau, warna dan rasa.

Islam merupakan agama yang bercirikan rahmah, mudah dan tidak membebankan umatnya dengan perkara-perkara yang tidak dapat ditentukan secara zahir. Adalah suatu yang membebankan jika umat Islam terpaksa memastikan diri mereka bebas sepenuhnya daripada terkena unsur najis yang terlalu halus atau kecil seperti sisa molekul atau nukleus yang sukar diteropong. Ciri-ciri rahmah ini jelas dinyatakan dalam nas-nas di bawah sebagai satu mesej penting yang perlu dihayati bagi memastikan kelestarian hukum syarak pada sepanjang zaman. Allah SWT berfirman di dalam al-Quran:

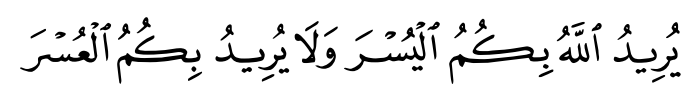

"(Dengan ketetapan demikian itu) Allah menghendaki kamu beroleh kemudahan, dan ia tidak menghendaki kamu menanggung kesukaran."

(Surah al-Baqarah, 2: 185)

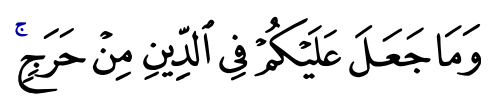

"Dan Dia tidak menjadikan kamu menanggung sesuatu keberatan dan susah payah dalam perkara agama."

(Surah al-Hajj, 22: 78)

Berasaskan prinsip-prinsip di atas, kenyahwujudan najis pada pakaian yang dibasuh menggunakan kedua-dua mesin itu sewajarnya telah dianggap bersih dalam konteks țhärah sebagai syarat sah ibadat solat, bukan sekadar menghilangkan kotoran najis (izālah al-najāsah) semata-mata.

Justeru, penggunaan mesin basuh dan dobi merupakan suatu inovasi basuhan pakaian yang boleh dimanfaatkan oleh umat Islam untuk kesenangan ibadat kepada Allah SWT jika terbukti ia mampu membersihkan najis. Islam tidak pernah bersikap skeptikal terhadap sebarang rekacipta orang bukan Islam, asalkan tidak menyalahi prinsip-prinsip hukum syarak yang jelas.

\section{RUJUKAN}

'Alī Jum'ah, al-Makāyil wa al-Mawāzin al-Shar'iyyah (Qāhirah: al-Quds li al-Nashr wa al-I'lān, 2001).

'Ațiyyah, 'Abd al-Hasib Sanad, 'Anwā' al-Taṭīr wa Shurūṭuhu,' http://www. alukah.net/sharia/0/44555/, dicapai pada 14 April 2019. 
Abī Dāwud, Sulayman Ibn al-Ash'ath al-Sijistānī al-'Azdī, Sunan Abī Dāwūd, ed. Muhammad Muhyy al-Dīn 'Abd al-Hamīd (Bayrūt: al-Maktabah al'Asriyyah, t.t.).

al-Bahūtī, Manșūr Ibn Yūnus Ibn Idrīs, Kashf al-Qinā' an Matn al-Iqnā', ed. Ibrāhim Ạ̣mad 'Abd al-Ḥamīd (Riyāḍ̣: Dār 'Alam al-Kutub, 2003).

Budowle B, Eisenberg AJ, van Daal A, 'Validity of Low Copy Number Typing and Applications to Forensic Science,' Croatian Medical Journal, vol. 50, no. 3 (2009): 207-217.

al-Bujayrimī, Sulaymān Ibn 'Umar Ibn Muhammad, Tuhfah al-Habīb 'alā Sharh al-Khātib (Bayrūt: Dār al-Fikr, 1995).

al-Bukhārī, Abī 'Abd Allāh Muḥammad Ibn Ismā'il al-Ju'fī, Șaḥịh al-Bukhārī, ed. Muḥammad Zuhayr Ibn Nașīr (t.t.p.: Dār Ṭawq al-Najāh, 2001).

Dār al-Iftā' al-Mișriyyah, 'Ṭahārah al-Malābis al-Najasah Idhā Wựii'at fī alGhasālāt al-Utūmātīkīh,' http://www.dar-alifta.gov.eg/ar/ViewResearch. aspx? sec=fatwa\&ID=151, dicapai pada 18 April 2019.

Darul Ifta, 'Washing Clothes via Washing Machine,'http://daruliftabirmingham. co.uk/washing-clothes-via-the-washing-machine/, dicapai pada 15 April 2019.

al-Dimyatī, Ab̄̄ Bakr 'Uthmān Muḥammad Shaṭa' al-Bakrī, Hāshiyah I'ānah al-Ṭālibìn (Bayrūt: Dār al-Fikr, 1997).

Gill P, Whitaker J, Flaxman C, Brown N, Buckleton J, 'An Investigation of the Rigor of Interpretation Rules for STRs Derived from Less Than 100 pg of DNA,' Forensic Science International, vol. 112, no. 1 (2000): 17-40.

Glaister, J., 'The Kastle-Meyer Test for the Detection of Blood: Considered from the Medico-Legal Aspect,' British Medical Journal, vol 1 (1926): 650-652.

al-Ḥațāāb, Abī 'Abd Allāh Muḥammad Ibn Muḥammad Ibn 'Abd al-Raḥmān al-Maghrib̄̄ al-Ra'yan̄̄, Mawāhib al-Jalīl li Sharh Mukhtașșar Khalīl, ed. Zakariyyā 'Umayrat (Bayrūt: Dār al-Kutub al-'Ilmiyyah, 1995).

Ibn 'Ābidīn, Muḥammad Amīn, Radd al-Muḥtār 'ala al-Durr al-Mukhtār (Bayrūt: Dār al-Fikr, 2000).

Ibn Haytham, Shihāb al-Dīn Aḥmad Ibn Hajar, Tuḥfat al-Muḥtāj bi Sharh alMinhāj (Qāhirah: Dār al-Ḥadīth, 2016).

Ibn Nujaym, Zayn al-Dīn Ibn Ibrāhīm, al-Baḥr al-Rā’iq Sharh Kanz alDaqā ’iq, vol. 1 (Bayrūt: Dār al-Kitāb al-Islāmī, t.t.). 
Ibn Taymiyyah, Abī 'Abbās Taqī al-Dīn Aḥmad Ibn 'Abd al-Halīm, Majmū' al-Fatawā, ed. 'Abd al-Raḥmān Ibn Muḥammad dan Muḥammad Ibn 'Abd al-Raḥmān (al-Madīnah al-Munawwarah: Mujamma' al-Mālik Fahd li Tibā'ah al-Mushaf al-Sharīf, 2004).

al-Iftā', 'Ḥukm al-Mā' al-Mutațāyir min al-Malābis al-Najasah Athnā' Ghasalaha,' https://aliftaa.jo/Question.aspx?QuestionId=2722\#.XNDzp zAzYdU, dicapai pada 18 April 2019.

Islamic Affairs \& Cheritable Activities Department, https://services.iacad.gov. ae/ SmartPortal/fatwa/PublishedFatwa/Deatils/26018, dicapai pada 18 April 2019.

Islamweb.net, 'Fatwa,' http://fatwa.islamweb.net, dicapai pada 18 April 2019. Jamāl Șāliḥ, 'Wasā’il al-Tațhīr' (Risālah al-Majistir fī al-Sharī'ah alIslāmiyyah, Jamī'ah al-Najah al-Wațāniyyah, Falaștīn, 2001).

John M. Butler, Advanced Topics in Forensic DNA Typing: Methodology (USA: National Institute of Standads and Technology Gaithersburg, Maryland, 2012).

al-Kāf, Hasan Aḥmad Muhammad, al-Taqrīrāt al-Sadīdah fì al-Masā'il alMufidah (Tarim: Dār al-'Ilm wa al-Da'wah, 2003).

al-Kasān̄̄, Abū Bakr Ibn Mas'ūd al-Hanāfî, Badā'i ' al-Ṣana 'i 'fì Tartīb al Sharā'i', ed. 'Alī Muḥammad Mu'awwad \& Ādil Aḥmad 'Abd alMawjūd (Bayrūt: Dār al-Kutub al-'Ilmiyyah, 2003).

Muhammad Hudzari Razali, Syazili Roslan, Muhammad Rahimi Osman, Muhammad Shahril Othman, Zulfakar Aspar \& Engku Fadzli Hasan Syed Abdullah, 'Development of Intelligence Technique in Syariah Compliance Washing Machine via PLC,' Journal of Artificial Intelligence, vol. 10, no. 2 (2017): 49-58.

Muslim, Ab̄̄ al-Husayn Muslim Ibn al-Hajjāj Ibn al-Qushayrī al-Naysabūrī, Șaḥ̄ḥ Muslim, ed. Muḥammad Fu'ād 'Abd al-Bāqī (Bayrūt: Dār Iḥyā' al-Turāth al-'Arabī, t.t.).

al-Nawawī, Abī Zakariyyā Maḥy al-Dīn Ibn Sharf, al-Majmū' Sharh alMuhadhdhab (Bayrūt: Dār al-Fikr, t.t.).

al-Nawawī, Abī Zakariyyā Maḥy al-Dīn Ibn Sharf, Asnā al-Mațālib fì Sharh Rawọdah al-Ṭālibīn (T.t.p: Dār al-Kutub al-'Ilmiyyah, t.t.).

al-Nawawī, Abī Zakariyyā Maḥy al-Dīn Ibn Sharf, Rawọah al-Ṭālibīn wa 'Umdah al-Muftīn (Bayrūt: al-Maktabah al-Islāmī, 1991).

Portal Rasmi Jabatan Kemajuan Islam Malaysia, 'Kemusykilan Agama,' http://kemusykilan.islam.gov.my/?data=O2thdGVnb3JpX2RldGFpbDs xMzE7\&page=871 dicapai pada 15 April 2019. 
Portal Rasmi Pejabat Mufti Wilayah Persekutuan, 'Menyucikan Pakaian Dengan Mesin Basuh,' http://www.muftiwp.gov.my/index.php/ms-my/ perkhidmatan/al-kafili-al-fatawi/1197-al-kafi-311-menyucikan-pakaian dengan-mesin-basuh, dicapai pada 15 April 2019.

al-Ramlī, Shams al-Dīn Muḥammad Ibn Ab̄̄ al-'Abbās Aḥmad Ibn Hamzah Ibn Shihāb al-Dīn, Nihāyah al-Muḥtāj Ila Sharḥ al-Minhāj (Bayrūt: Dār al-Kutub al-'Ilmiyyah, 2003).

al-Rayyashī, Șāliḥ Hasan, al-Sharh al-Manhajī al-Mu'āṣir li Alfāz al-Faqīh Abì Shujā' al-Shāfi 'ì (Bayrūt: Dār Ibn Hazm, 2013).

Rizuwan Yahaya, Mohd. Huzari Razali, Basri Ibrahim, Mohd Shahril Othman, Noordin Asimi Mohd Noor, Hasbullah Muhammad \& Soran Jalal Abdullah, 'Conceptual Instrumentation of Washing Machine for Conformity to the Islamic Laws of Syarak,' Scientific Journal of Review, vol. 2, no. 6 (2013): 151-155.

Rozaimi Ramle, 'Hukum Menggunakan Mesin Basuh Yang Sama Dengan NonMuslim?’ https://www.facebook.com/DrRozaimiRamle/posts/152342 2311018597, dicapai pada 15 April 2019

al-Șan‘ān̄̄, Muḥammad Ibn Ismā'īl al-Kahlan̄̄ Abū Ibrāhim, 'Izz al-Dīn, Subl al-Salām Sharḥ Bulūgh al-Maram (Qāhirah: Dār al-Ḥadīth, t.t.).

al-Sharbīnī, Shams al-Dīn Muḥammad Ibn Muhammad al-Khāṭib, Mughnī al-Muhtāj ilā Ma 'rifātī Ma'ānī Alfāz al-Minhāj, ed. 'Alī Muhammad Mu'awwad dan 'Ādil Ahmad al-Mawjūd (Bayrūt: Dār al-Kutub al'Ilmiyyah, 1994).

al-Shawkānī, Muḥammad Ibn 'Alī Ibn Muḥammad, Nayl al-Awṭār, ed. 'Ișām al-Dīn al-Ṣabābuṭī (Qāhirah: Dār al-Ḥadīth, 1993).

T.p., 'Hukum Guna Pakaian Dibasuh dengan Mesin Basuh Automatik,' Youtube, https://www.youtube.com/ watch?v=A0F29gZu5qA, dicapai pada 15 April 2019.

T.p., 'Hukum Menggunakan Mesin Cuci Baju,' http://naaimahbtenaaim. blogspot.my/2017/09/hukum-menggunakan-mesin-cuci-baju.html., dicapai pada 15 April 2019.

Wahbah al-Zuhaylī, al-Fiqh al-Islāmī wa Adillatuh (Dimashq: Dār al-Fikr, 1989). 